\title{
FINANCIAL SECURITY AND ECONOMIC DEVELOPMENT: METHODS OF ANALYSIS AND RISK MANAGEMENT (THE CASE OF RUSSIA)
}

\author{
Natalia Kazakova
}

Anna Sivkova

Plekhanov Russian University of Economics, Russia

Under the conditions of today's megarisks, the general level of instability of the world economy is only rising, the number of unprofitable organizations with overdue debts increases, and this creates additional threats to financial security of the states. In this regard, the presented research results have scientific and applied importance for risk management of financial security of economic entities on the basis of the suggested control and analytical concept. The suggested concept includes; monitoring, diagnostics, prevention of crisis situations, including bankruptcy, corporate fraud or financial irregularities in the economy. Accounting for the specifics of economic entities in the analysis, diagnostics and control of their activities is aimed at developing an effective management system for corporate fraud and bankruptcy prevention. The conceptual principles of information and analytical support, improved methods used in analyzing, evaluating and monitoring financial security contribute to the development of this methodology for economic analysis and control, ensuring their effectiveness and transparency. The comprehensive toolkit offered here for diagnosing financial security allows identifying the areas of increased bankruptcy risks, fraudulent actions or ineffective business management; unify the control process, thereby reducing labor intensity and improving the quality of control measures.

Keywords: financial security; financial risks; bankruptcy; corporate fraud; monitoring.

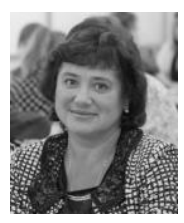

Natalia A. Kazakova

Doctor of Economic Sciences, professor of the Financial Management Department, Director of the Center for Financial Studies, Plekhanov Russian University of Economics, Russia

Sphere of professional activity: scientific and practical issues of financial analysis, business process diagnostics, bankruptcy and risk assessment of the company's financial security.

Since 1997 he has been engaged in professional analytical work in state and commercial organizations.

E-mail: yananda_nam@hotmail.com yananda.si@ssru.ac.th

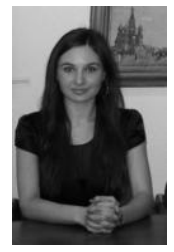

Anna E. Sivkova

Assistant at the Financial Control, Analysis and Audit Department, post-graduate student of the Financial Management Department,Plekhanov Russian University of Economics, Russia

Sphere of professional activity: certified professional accountant of the Russian Institute of Information Technologies. She is engaged in problems of financial analysis, diagnostics of bankruptcy risks, transformation of reporting and implementation and application of IFRS in Russian companies.

Has practical experience of analytical work in the department of tax and legal consulting in the international company "Deloitte and Touche CIS".

She has omore than international publications. 


\section{Introduction}

Public policy today is facing a series of problems due to the increased levels of macroeconomic, global and international risks. That is why strengthening economic security, in any country worldwide, means developing specific new mechanisms, methods and tools.

Economic security is one of the conditions for sustainable development. These conditions determine the quality status of the overall socioeconomic environment, which ensures sufficient independence of management, the financial system stability, the reserve of economic strength. Government creates and maintains their own resources, thus strengthening the comprehensive capacity and opportunities to reduce the negative effects from the crisis phenomena in the national, regional and global economies at the same time. The most important economic security factor is efficient functioning of the leading companies, no matter what is their sector, or size, or property form.

Financial security is always based on the strategic programs of increasing the investment attractiveness of the state economy and also on the financial security diagnostic's system. In this way, a complex of state measures must be development so that to detect and increase financial stability and reliability of companies. If companies have low financial transparency concerning their economic activities, industrial cooperation and other forms of partner companies' relationship would be difficult; moreover, this may lead to a situation when investment processes would slow down in the economy of the whole country. This means that financial security and risk protection of business partnerships is the most important foundation of all future investments into the country.

Analysis, evaluation, prediction, diagnosis and monitoring of financial security of companies and consolidated businesses as well is an integral part of contemporary financial management in a new economy situation which today is characterized by: high level of financial risks, rapid changes in external and internal factors of the organizational environment, growing threats to financial interests of many businesses.

\section{Analysis of the risks related to financial violations in Russia and the selected other countries}

Russian economic realia of today include the following economic crimes: fraud, illegal appropriating, illegal entrepreneurship, criminal bankruptcies, tax avoidance and other forms of taxation rules' violations. The most common of them, causing direct damage to many businesses all over the country, are: fraud (Article 159 of the Criminal Code), appropriation and fraud (Article 160 of the Criminal Code of the Russian Federation). Many researchers studying this topic as applied to Russian practice have detected high degree of latency in intra-firm fraud in particular (which is hidden, disguised).

The number of fraud cases and other economic crimes is roughly around 5\% of all criminal acts in Russian Federation, according to some estimates. However, we have reasons to assume that the actual amount of damages exceeds significantly the official data. Thus, we also assume that intra-firm fraud and other related economic crimes constitute a much larger share in the total number of crimes. This type of crimes inflicts enormous harm to particular enterprises and also to the interests of the budget, since intra-firm economic crimes often lead to shortage of tax payments. The damage from fraud and other economic crimes has a 


\section{FINANCIAL SAFETY AND ECONOMIC DEVELOPMENT:}

strongly influences during the sanctions period for Russia, it undoubtedly reduces the level of financial security of the state.

According to Sheila R. Ronis (2011), financial security is an important element of national security. From all sides and theories, national security is the field of economic viability of the people.

Hyide, H.K., Panos, G.A. (2014) have allocated two elements of fraud: denomination and trust. Without trust, fraud is impossible.

The Association of Certified Fraud Examiners (ACFE) use the proprietary approach according to which fraud and abuse is part of professional activity of a person used in his/her official position for the purposes of personal enrichment through deliberate misuse or abuse of the resources and/or assets of an organization/employer.

According to Art. 159 of the Criminal Code of the Russian Federation, "fraud" means the theft of someone's property or acquisition of the right to someone's property by misconception or abuse by trust. It also says that internal or corporative fraud means fraudulent operations between an employer and a worker or between a worker and an employer.

The Ministry of Finance of Russia states that the work of the Associate of Certified Fraud Examiners (ACFE) has three categories of corporate fraud (the so-called "fraud tree"): 1. bribery and corruption (in Russia $-40 \%$ of all cases, in the world $-24 \%$ of all cases); 2 . falsification of accountability, completion and closing of falsified accounting records, falsifications related to taxes' collection (in Russia and in the world - approximately 25\%); 3. Assets of unlawful appropriation (approximately same level in the world and in Russia around $72 \%$ ) (Federal State Statistics Service, official website).

In the world intra-firm fraud ranking Russia occupies the first place (71\%), South Africa goes second $(62 \%)$, and Kenya is third. (57\%). Surprisinly, Canada is the $4^{\text {th }}(56 \%)$, Mexico - the 5th (51\%) (this ranking is provided on the basis of the $\mathrm{PwC}$ research study titled "Economic crimes during the period of economic expansion"). 59\% of all domestic companies in the last two years became the victims of some sort of economic crimes, this is much higher than the world average indicator (43\%).

Russia's first place can be also explained by the low quality of corporate management: a significant share of managerial personnel directly participates in various criminal schemes in Russia, while in Western countries it is mainly mid-level and linear personnel participating in such criminal affairs (Kazakova et al., 2017).

British audit company "PricewaterhouseCoopers" periodically carries out the studies concerning economic violations worldwide, and some of their results concerning Russia can be called truly horrific: during the last two years damages caused by personnel fraud in Russian companies have quadrupled, and the amount of losses from one such act is five times higher than in the average world indicator. According to the results of this study, more than five thousand companies in Russia, including 120 largest companies in the country, suffer losses due to corruptive fraud. This indicator exceeds the average world indicator by more than $15 \%$.

In today's Russian and international practice, the term "corporate fraud" is used to express unscrupulous, deliberate actions of personnel entailing various financial violations aimed at obtaining personal benefits.

In Russian practice, there is only one legal term for fraud, defined by Art. 159 of the Criminal Code, and it is actually "fraud" as such. Other unscrupulous acts can be also 
classified as fraud leading to bankruptcy. According to the federal auditing standards of the Russian Federation, fraudulent actions with the aim of extracting illegal benefits are considered to be unfair, leading to significant distortions in financial statements.

The fight against in-firm fraud is the subject of improving regulatory, departmental legislation and by-laws as well as the improvements in regulatory framework of large financial companies, mortgage lending, public health financing and other areas of activities. Fraud also means manipulating financial reporting, trading operations and abuse of trust. A series of recent major scandals have revealed the facts of corporate fraud that occurred over the past decade, leading gradually to the understanding that identifying corporate fraud has become a particularly relevant issue. Widespreadly infamous became such companies and organizations as ENRON, WorldCom, LG Group, Mercury Finance Company, British Petrolium, Hollinger International Inc. and Parmalat.

The international experience of fighting unfair business practices officially began back in 1960 with the establishment of the Committee of Insolvency Professionals within the framework of the European Union. Its most important achievement was the development of a set of measures regulating the procedures for companies' bankruptcy on the territory of the European Union. But this regulation includes only mandatory bankruptcy procedures, and those are also regulated by national legislation in different countries (Blaskowitz \& Herwartz, 2011).

USA is one of the countries that carry out most active work on the development of mechanisms for counteracting economic crimes. Unlawful actions related to bankruptcy, according to the US legislation, also cover concealing assets. Other widely spread types of economic crimes include: provision of falsified or incomplete data on creditors; bribery of the appointed arbitration administrator etc.

Detection and prevention of fraudulent activities is handled by the Financial Fraud Enforcement Task Force with the assistance of the Federal Bureau of Investigation, the Securities and Exchange Commission, the Industrial Finance Regulatory Committee, the Internal Revenue Service and the Labor Department. The most significant result of the US government's efforts to combat corporate fraud is the creation of the Financial Crimes Enforcement Network (FinCEN), which has an extensive database which serves as a platform for interaction between various special services (Sedova et al., 2017).

In recent decades, apart from the efforts taken by individual countries in the direction of economic crimes' prevention, international organizations and associations have been also established. The most famous international organization in this field today is the Association of Certified Fraud Examiners (ACFE), which deals with the problems of financial fraud, including unscrupulous bankruptcy actions. This organization has a branch in Russia as well. The Association conducts training for specialists to identify and investigate various types of economic crimes, including corporate fraud, develop methodological recommendations that contain examples of how to combat unfair economic activities, and also collects statistical data for the consolidated database of identified economic crimes.

Obtaining information from the monitoring activities should be aimed at preventing fraud within organization, identifying its potential causes and eliminating fraud at its initial stage of development. 


\section{FINANCIAL SAFETY AND ECONOMIC DEVELOPMENT:}

\section{Directions in assessment, diagnostics and control of financial security of economic entities}

Security problems of company's activities are often related to growing instability in the economy due to the financial crisis, fluctuations in oil prices and subsequent political decisions and economic sanctions, which ultimately lead to increased financial risks for all organizations within the country. Financial stability is an integrated indicator of company's activities, as it reflects the effectiveness of company's management and shows how stable the organization can be under the conditions of high micro- and macrorisks. Development of the security control methodology can be presented in several stages, including the identification of security risks, determination of directions in monitoring, development of financial and economic indicators and safety monitoring criteria, and finally, definition of an information and analytical framework for security analysis and monitoring.

\section{Identification of security risks and the control directions}

The first stage begins directly with the procedure for identifying risks and determining the directions for controlling financial security. External threats to a company are caused by geopolitical relations and relations between the states, for example, imposition of sanctions on certain goods and, accordingly, restriction of all related activities; instability of the exchange rate of the domestic currency; monetary defaults and sharp rises in the inflation level; changes in the legal framework; growth of interest rates on loans; unfair competition and fraud; high level of financial crimes in the country overall.

Internal threats to business are caused by unethical work of personnel, low level of its qualifications and poor quality of work; corporate fraud cases; insufficient supervision by management; outdated technical basis and malfunctioning of equipment; low level of assets' liquidity; leakage of information, fall of company's reputation; lack of development plans, ineffective company policies and unjustified management decisions.

In order to ensure the financial security of a company, it is necessary to build an internal control system with determined in advance responsibility centers, for which it is required in accordance with the specifics of a particular business to determine the directions of control, subjects of control, the system of financial and economic parameters and criteria for monitoring financial security, as well as the information and analytical basis for monitoring, methods to identify the risks of financial security, principles of ensuring the security of a business entity. We assume that the objects of control over the security of the activities at an economic entity can be:

- Assets (property);

- Information;

- Staff;

- Information resources (databases);

- Company's reputation.

Table 1 presents the distribution of security risks of the business entity's activities on the proposed control objects 
Table 1. Security risks' distribution between the economic entities' activities as the objects of control

(Source: compiled by the authors)

\begin{tabular}{|c|c|c|c|}
\hline $\begin{array}{l}\text { Objects of control } \\
\text { (security centers } \\
\text { inside a business } \\
\text { entity) }\end{array}$ & Controlled risks & $\begin{array}{c}\text { Causes (factors) of potential } \\
\text { risk }\end{array}$ & Controllers \\
\hline $\begin{array}{l}\text { Property (assets) of } \\
\text { the company }\end{array}$ & $\begin{array}{l}\text { Possibility of theft of easily } \\
\text { available assets; } \\
\text { re-ownership of property of the } \\
\text { company; damage to or } \\
\text { destruction of property which } \\
\text { belongs to the company; } \\
\text { prevalence of financial } \\
\text { liabilities. }\end{array}$ & $\begin{array}{l}\text { Dishonesty and negligence } \\
\text { of staff; insufficient } \\
\text { supervision by management. }\end{array}$ & $\begin{array}{c}\text { Heads of } \\
\text { departments; } \\
\text { Financial Director; } \\
\text { Legal service; } \\
\text { Internal auditors; } \\
\text { Controllers; } \\
\text { External Auditors. }\end{array}$ \\
\hline Information & $\begin{array}{l}\text { Leakage of confidential } \\
\text { information (recipes / } \\
\text { production technologies, } \\
\text { know-how, investment } \\
\text { projects' information etc.); } \\
\text { absence or violation of } \\
\text { regulated procedures on the } \\
\text { transfer and use of } \\
\text { information. }\end{array}$ & $\begin{array}{l}\text { Insufficient control by } \\
\text { management; low trust } \\
\text { among staff; ill-conceived } \\
\text { resolution of issues by } \\
\text { lawyers (e.g., text of } \\
\text { confidentiality agreements); } \\
\text { improper distribution of the } \\
\text { levels of secrecy and/or } \\
\text { access to information. }\end{array}$ & $\begin{array}{c}\text { Heads of } \\
\text { departments; } \\
\text { Financial Director; } \\
\text { Legal service; } \\
\text { IT-department. }\end{array}$ \\
\hline Staff & $\begin{array}{l}\text { Damage to the company in the } \\
\text { form of selling unprofitable or } \\
\text { directly unprofitable business } \\
\text { operations; falsification of } \\
\text { financial documents; fraud on } \\
\text { the part of staff; } \\
\text { corruption, blackmailing, } \\
\text { threats on the part of third } \\
\text { persons; luring important } \\
\text { employees to other companies; } \\
\text { abuse of office. }\end{array}$ & $\begin{array}{l}\text { Insufficient control by } \\
\text { management;trust issues; } \\
\text { insufficient control by } \\
\text { lawyers. }\end{array}$ & $\begin{array}{c}\text { Heads of } \\
\text { departments; } \\
\text { Financial Director; } \\
\text { Legal service; } \\
\text { Personnel service. }\end{array}$ \\
\hline $\begin{array}{c}\text { Information resources } \\
\text { (databases) }\end{array}$ & $\begin{array}{l}\text { Hacking, defacing, destruction } \\
\text { of databases; leakage of } \\
\text { confidential information, } \\
\text { financial losses (costs of } \\
\text { restoring information). }\end{array}$ & $\begin{array}{c}\text { Weak technical support } \\
\text { (insecurity from viruses and } \\
\text { unauthorized access); abuse } \\
\text { of office. }\end{array}$ & $\begin{array}{l}\text { IT-department. Top } \\
\text { management. Heads } \\
\text { of departments. }\end{array}$ \\
\hline Reputation & $\begin{array}{l}\text { Reclamation of products } \\
\text { (works, services); "creative" } \\
\text { accounting; instability of } \\
\text { contractual relations; } \\
\text { damaging information in } \\
\text { media; getting into "black } \\
\text { lists" of organizations, } \\
\text { unreliable customers of banks, } \\
\text { taxpayers, suppliers etc. }\end{array}$ & $\begin{array}{l}\text { Lack of competence, } \\
\text { integrity, qualification of } \\
\text { personnel; violation of } \\
\text { normative regulations; } \\
\text { untimely response to } \\
\text { partners' complaints; } \\
\text { illegitimate attitude in } \\
\text { business and in the business } \\
\text { environment. }\end{array}$ & $\begin{array}{c}\text { Company's } \\
\text { management team; } \\
\text { Top management; } \\
\text { Heads of } \\
\text { departments. }\end{array}$ \\
\hline Financial indicators & $\begin{array}{l}\text { Insolvency (bankruptcy); loss } \\
\text { of financial stability; illiquidity } \\
\text { of assets. }\end{array}$ & $\begin{array}{l}\text { Lack of business planning; } \\
\text { low quality of accounting } \\
\text { and control. }\end{array}$ & $\begin{array}{l}\text { Financial Director; } \\
\text { Controllers; } \\
\text { Internal auditors; } \\
\text { External auditors. }\end{array}$ \\
\hline
\end{tabular}




\section{FINANCIAL SAFETY AND ECONOMIC DEVELOPMENT:}

The control centers for security of a business entity may include such significant management and external control subsystems as personnel department, top management, internal control or internal audit service, external controllers represented by audit organizations, representatives of counterparties, tax authorities, international organizations etc. In order to lower the security risks of the business entity's activity by these control centers, we propose the following recommendations:

1. Professional development of accounting and financial personnel;

2. Improvement of top management's skills;

3. Continuous monitoring, analysis and assessment of the level of financial security of the company, continuous and mandatory legal support;

4. Improving the effectiveness of the internal control system (double control, increased attention to atypical operations, availability of internal audit, annual independent audits initiated by the company itself);

5. Compliance with strict cash, tax and payment discipline;

6. Control over the performance of marketing, distribution and personnel policies;

7. Improving the security of internal information systems.

\section{Financial and economic indicators and criteria for monitoring the security of a business entity}

Security of a business entity is determined by the maintained level of its general stability and also financial stability of the company, by the sufficiency of funds necessary for operations, by the rate of financial and investment activities and the balance of cash flows, and also by company's relative independence from counterparties and business partners.

To monitor the security level of an economic entity certain requirements must be taken into account:

- measurability of financial security parameters (availability of qualitative and quantitative indicators);

- presence of threshold values, which can be used to assess the financial security level of a business.

In addition, control over the business entity security must ensure the development of its integrated capacity, its cost growth and its financial stability in both long-term and short-term periods. Table 2 systematizes the company's financial security indicators, distributed by the control centers.

Express analysis of financial security of a business entity can be carried out on the basis of accounting data. It is used not only to determine the position of an organization, but also to assess the effectiveness of management ensuring its financial stability.

Organization and functioning of the system of internal control over the financial security of an economic entity should be based on the principles of complexity, timeliness, continuity, legality and accounting.

The principle of complexity means ensuring security of personnel, of the company's assets, its information databases and confidentiality of information from all types of threats. This is achieved through personnel selection policy, using various technical security and information protection tools. Information analysis in this case is also aimed at preventing potential risks to company's financial security. 
Table 2. Distribution of security indicators of the business entity's activity by control centers

(Source: compiled by the authors on the basis of the Federal State Statistics Service, official website)

\begin{tabular}{|c|c|c|}
\hline $\begin{array}{l}\text { Financial security } \\
\text { control centers } \\
\text { (control objects) }\end{array}$ & Indicators & Financial characteristics \\
\hline $\begin{array}{l}\text { Property (assets) } \\
\text { of the company }\end{array}$ & $\begin{array}{l}\text { Short-term liquidity } \\
\text { ratio } \\
\text { Accounts receivable } \\
\text { turnover } \\
\text { Turnover of } \\
\text { inventories } \\
\text { Average period of } \\
\text { inventory turnover }\end{array}$ & $\begin{array}{l}\text { Shows the company's ability to meet current obligations using } \\
\text { liquid assets. In the process of working on revealing the facts of } \\
\text { fraud, the current liquidity ratio can be the indicator of } \\
\text { manipulations in accounting. Embezzlement will reduce this } \\
\text { ratio. Withholding obligations will give it a higher value. } \\
\text { Shows the company's ability to cover unexpected cash } \\
\text { requirements, can act as the indicator of fraud. } \\
\text { Shows how many times the accounts of debtors turn around } \\
\text { during the reporting period. In other words, it indirectly } \\
\text { characterizes the time between the receipt of receipts and } \\
\text { accounts receivable for the accounting and receipt of cash in } \\
\text { payments. If there are cases of fictitious sales, money for them } \\
\text { will never be received. As a result, the turnover of receivables } \\
\text { will decrease. } \\
\text { This ratio is a good characteristic of the efficiency of purchases, } \\
\text { production and sales. For example, if the cost of sales rose due to } \\
\text { theft of inventory (inventory at the end of the period decreased, } \\
\text { but it was not because of their sales), then this ratio will be } \\
\text { higher than the normal value. } \\
\text { Increase in the number of days when inventories are left in stock } \\
\text { (a decrease in turnover) causes additional costs, including storage } \\
\text { costs, the risk of inventory obsolescence, a decline in the market } \\
\text { price, and interest and other costs arising from the freezing of } \\
\text { funds in inventories. Inconsistencies and significant fluctuations } \\
\text { of this coefficient may indicate the presence of signs of possible } \\
\text { fraud. We can use this factor when studying the inventory } \\
\text { accounts to identify possible theft. }\end{array}$ \\
\hline Company staff & Staff turnover rate & $\begin{array}{l}\text { The extreme instability of staff may indicate the presence of } \\
\text { financial problems in the company and indirectly, this can be } \\
\text { also a sign of fraud. }\end{array}$ \\
\hline Reputation & $\begin{array}{l}\text { The amount of } \\
\text { costs associated } \\
\text { with complaints for } \\
\text { products (work, } \\
\text { services) }\end{array}$ & $\begin{array}{l}\text { Growth of other expenses due to economic sanctions, supply } \\
\text { disruptions, increase in product returns, which may be the signs } \\
\text { of financial irregularities and other problems }\end{array}$ \\
\hline Financial risks & Profit margin ratio & $\begin{array}{l}\text { Shows the balance between the resources provided by creditors } \\
\text { and the resources provided by owners. This can be the most } \\
\text { important for analyzing the financial situation of a company. } \\
\text { Maintaining a certain ratio of borrowed funds and equity is often } \\
\text { included in texts of loan agreements. Unexpected changes in this } \\
\text { coefficient may serve as the sign of financial irregularities. } \\
\text { The ratio of net profit to sales proceeds reflects not only changes } \\
\text { in the gross profit margin, but also changes in trade and } \\
\text { administrative expenses. When there is fraud, artificially inflated } \\
\text { sales will not be accompanied by an increase in the cost of sales, } \\
\text { net profit will be overstated, and the profit margin will be } \\
\text { unusually high. Fictitious expenses and fraudulent payments will } \\
\text { lead to increased costs and reduced profitability. }\end{array}$ \\
\hline
\end{tabular}




\section{FINANCIAL SAFETY AND ECONOMIC DEVELOPMENT:}

The principles of timeliness and continuity assume the existence of a system used for constant monitoring and maintenance of the company's current and future state, which is ensured by constant analysis and forecasting of security threats to the company as well as the development of effective protection measures.

The corporate fraud's increased risks are associated with insufficient control measures which are supposed to be aimed at preventing and detecting fraud; wide range of powers granted to one employee; lack of a system for assessing staff performance; impunity, disregarding the rules of professional ethics; anti-organizational culture; easy access to confidential information for outsiders; high risks of the distortion or lack of information; incompetence and insufficient qualifications of personnel; problems with internal and external audit.

The most common types of fraud on the part of employees include:

- counterfeiting (falsification) of documents;

- conducting transactions with controlled companies;

- collusion with customers or with suppliers; invoicing for uncompleted work or undelivered goods;

- the use of a kickback system;

- use of shell suppliers or intermediaries; artificial overstatement of prices;

- use of employees, equipment, materials or resources of the company for personal purposes;

- illegal cancelling of property;

- application of computer crime technologies;

- use of cash for other purposes.

Other high-risk attributes of fraud inside an organization can be as follows:

- too complicated or illogical organizational structure;

- failures with carrying out audits;

- activities in the areas related to high-risk operations;

- frequent change of senior and middle managers;

- large transactions with affiliated persons and interested companies.

In the process of detecting corporate fraud facts analytical procedures are often used to identify the signs of fraud. Inter alia, they can reveal atypical or implausible contracts to be believed it. These can be actions or events occurring in strange places or at unusual times; transactions involving individuals who do not normally have to participate in these relations, and also, committing strange procedures or using non-standard methods in financial operations. Bad signs can be also too large (too small) transactions or transferred amounts; transactions that are carried out too often or too rarely, involving too large or very small amounts, leading to extremely high profit or not providing profit as such.

The analytically detected features of fraudulent operations can be everything that goes beyond usual operations, that is, operations typical for this particular sector and this specific company. 


\section{Solutions and Recommendations}

Basing on the study and generalization of the experience with control and diagnostic measures, we have developed and are offering the following observations to be taken into account in the course of internal control over the security of economic entities, aimed at identifying fraud.

1. The most common facts of fraud are found in the service sector because provision of services is the hardest to verify.

2. Under fictitious transactions, figures in financial statements can be real (reliable), but all the fraudulent facts will be hidden in interim documents and intermediate reports, which are not publicly available.

3. Fraudulent transactions are mostly hidden inbetween the actions that were actually committed (for example, you can confirm the fact of purchase, but using another amount).

4. If facts of fraud using computer technologies or databases are established, then, as a rule, this has been done with direct participation of a specialist from the local IT department.

5. Most of the fraud facts are hidden via manipulations with primary documents.

6. Accounting has its own signs that may indicate the presence of potential corporate fraud and, therefore, require detailed control, for example: accounts receivable grow much faster than the revenue; the wage bill increases while the number of personnel is decreasing; increase in investment in the absence of growth in depreciation of fixed assets; writing off equipment before the deadline; availability of products and materials not registered in accounting.

7. To reduce the risks of corporate fraud, it is recommended to use organizational methods such as: segregation of duties; double control; system of authority confirmation; independent checks; documentary control.

8. To identify fraudulent operations, we can recommend the internal audit methods: checking the accuracy of calculations (analysis of the correctness of calculations, recalculation); analytical tests (verification of causation); checking the completeness of documentation; verification of the procedures used in approving documents; verification of legitimacy (legality of business transactions); conducting interviews with staff concerning the performance and activities of the company.

\section{Conclusion}

The key result of this study is the developed author's conceptual approach to information and analytical provision of financial security for business entities which involves accounting for the specifics of economic sectors, determining the directions of control and its subjects, the system of financial and economic parameters and criteria for monitoring security, developing an information-analytical bases for control, methods for identifying the security risks of an economic entity. In particular, we have proposed here such responsibility centers and objects of control over the security of a business entity: assets (property), information, personnel, information resources (databases), and company's reputation.

As typical control and diagnostic measures for the business entity security, including fraud detection, we recommended the following:

- carrying out control actions: external and internal audit; supervision over corporate culture; double control; independent control; confirmation of authority; 


\section{FINANCIAL SAFETY AND ECONOMIC DEVELOPMENT:}

- control of the personnel policy, including the inspection of personnel and delineation of powers;

- organizational arrangements aimed at delegating authority to prevent possible collusion between employees, customers or suppliers;

- carrying out information and psychological activities aimed at informing company's partners about its policy to fight against violations and abuses, operation of a "hot line" to receive anonymous messages, publicly announced punishment for perpetrators;

- introduction of a specifically designed workflow system;

- introduction of rules for collegial decision-making and independent coordination of documents;

- transparency in contractual relations and business processes, complete legality of the company.

\section{References}

Blaskowitz, O., Herwartz H. (2011). On economic evaluation of directional forecasts. International journal of forecasting, 27 (4), 1058-1065. DOI: 10.1016/j.ijforecast.2010.07.002

Criminal Code of the Russian Federation (1997).

Federal State Statistics Service: official website. http://www.gks.ru

Hyide, H.K., Panos, G.A. (2014) Risk tolerance and entrepreneurship. Journal of Financial Economics, 111(1), 200-223. DOI: 10.1016/j.jfineco.2013.06.001

Kazakova, N.A., Bolvachev, A.I., Gendon, A.L., Golubeva, G.F. (2016) Monitoring Economic Security in the Region Based on Indicators of Sustainable Development. Studies on Russian Economic Development, 27 (6), 650-660. DOI: 10.1134/S1075700716060058.

Kazakova, N.A., Bolvachev, A.I., Gendon, A.L., Golubeva, G.F. (2017) Value Added Analysis and Trend Forecasting in the Manufacturing Industry in Kaliningrad Oblast. Studies on Russian Economic Development, 28(2), 160-168. DOI: 10.1134/S107570071702006X.

Report to the nations on occupational fraud and abuse official website (ACFE). (2016) Retrieved from http://www.acfe.com/rttn.aspx.

Ronis S. R. (2011) Economic Security. Neglected Dimension of National Security? National Strategic Studies by National Defense University, 116.

Sedova, N.V., Kazakova, N. A, Gendon, A. L., Khlevnaya, E. A. (2017). Prediction of development in the mining and chemical industry in Russia and in the world. GORNYI ZHURNAL, (4), 4952. DOI: $10.17580 /$ gzh.2017.04.09.

Statistics on the judicial practice of the RF Arbitration Courts in bankruptcy cases. Retrieved from: http://sudact.ru/arbitral/stats/?law_stat_category=s

RE7Jt1f1fV8\&date from $=01.01 .2015 \&$ workflow_stage $=$ DKnC6cEIq7Vv\&date_to=20.11.2015.

Paper submitted

Paper accepted for publishing

Paper published online
07 December 2017

11 February 2018

30 March 2018 